\section{INVESTIGATION OF CONTACT FORMATION DURING SILICON SOLAR CELL PRODUCTION}

\section{Barbora Mojrová}

\begin{abstract}
- this article deals with the investigation of the influence of sintering conditions on the formation process of screen printed contacts on passivated boron doped $\mathrm{P}^{+}$emitters. The experiment was focused on measuring of resistance changes of two thick film pastes during firing processes with different conditions. Two different temperature profiles were compared at an atmospheric concentration of $\mathrm{O}_{2}$. The influence of the $\mathrm{O}_{2}$ concentration on resistance was investigated for one profile. A rapid thermal processing furnace modified for in-situ resistance measurements was used. The change of resistance was measured simultaneously with the temperature.
\end{abstract}

Keywords: silicon solar cell, metallization, contacts formation, $\mathrm{N}$-type, in-situ resistance measurement

\section{INTRODUCTION}

One way to increase crystalline silicon solar cell efficiency is based on an optimization of a metallization. Two main loss mechanisms are related to the metallization, optical shading losses and electrical series resistance losses. Requirements for contacts are low contact resistance to silicon, low line resistance, a negligible effect on a substrate, good line resolution, solderability, good adhesion, and low cost [1].

The screen printed metallization is the main technique used in industry due to its simplicity, a process speed and a price. The thick film pastes for the solar cell metallization are composed of a solvent system, inorganic powders, metal powders and a glass frit. The mixture of metal powders consists silver and aluminum most often. Using a glass frit with low transformation temperatures (typically lead borosilicate glass) allows peak firing temperatures below $\nu=850^{\circ} \mathrm{C}[1,2]$.

The printed contacts are dried and subsequently fired in a furnace at high temperatures which are necessary to open an antireflection and passivation layer and to support the reactions in the course of firing. During the firing, the organic ingredients of the paste are thermally decomposed, the glass frit melts and wets the contact interface. The fluidized glass frit is known to etch through the antireflection and passivation layer and to react with the emitter, which enables crystallites to nucleate at the glass-silicon interface to form an electrical contact with the emitter. During the peak zone, where the wafer is heated within seconds up to temperature of approximately $800^{\circ} \mathrm{C}$, the actual contact formation occurs. The cooling is usually as fast as the heating process [1-3].

\section{CONTACT FORMATION MEASUREMENT}

\subsection{Sample preparation}

For this experiment were used 6 inch N-type monocrystalline silicon substrates after cleaning, saw damage removal and texturing. A high conductive layer of the emitter $(60 \Omega / \mathrm{sq})$ was created by atmospheric pressure diffusion using $\mathrm{BBr}_{3}$ as a source. A $70 \mathrm{~nm}$ thick dielectric layer of $\mathrm{SiO}_{2}-\mathrm{SiN}_{X}$ was deposited as a passivation and antireflection layer using plasma enhanced chemical vapour deposition.

The influence of sintering conditions was observed using two different silver pastes from various producers (named A and B). Both pastes are designated for fine line front side metallization. The testing structure was created by $4 \mathrm{~mm} \times 1 \mathrm{~mm}$ screen printed spots at $50 \mathrm{~mm}$ distance. This structure was chosen due to simply positioning of measuring contacts.

\subsection{Firing conditions}

The measurements were done for two temperature profiles varying in the first target temperature $\nu_{H}$, which was $\nu_{H}=480{ }^{\circ} \mathrm{C}$ for Profile 480 and $\nu_{H}=400^{\circ} \mathrm{C}$ for Profile 400. The parameters of respective profiles are described in the Tab. 1. The $\mathrm{O}_{2}$ concentration at the first measurements for both profiles was coincident with the concentration in the atmosphere $\left(21 \% \mathrm{O}_{2}\right)$. Afterwards it moved downwards to $10 \%, 5 \%$, and finally $0 \%$ in the case of the Profile 480. The required concentration of $\mathrm{O}_{2}$ was achieved by controlling the variation of the $\mathrm{O}_{2}$ concentration in the $\mathrm{N}_{2}$ atmosphere. In case of the Profile 400 only the measurements with $21 \% \mathrm{O}_{2}$ were done.

\subsection{In-situ resistance measurement}

A rapid thermal processing furnace modified for an insitu resistance measurement was used and the resistance was measured using four point method. Two molybdenum alloy probing wires were encapsulated in a ceramic guide jacket and contacts the paste spots on the substrate

\footnotetext{
* Department of Microelectronics, Faculty of Electrical Engineering and Communication, Brno University of Technology, Technická 3058/10, Brno 616 00, xmojro00@stud.feec.vutbr.cz
} 

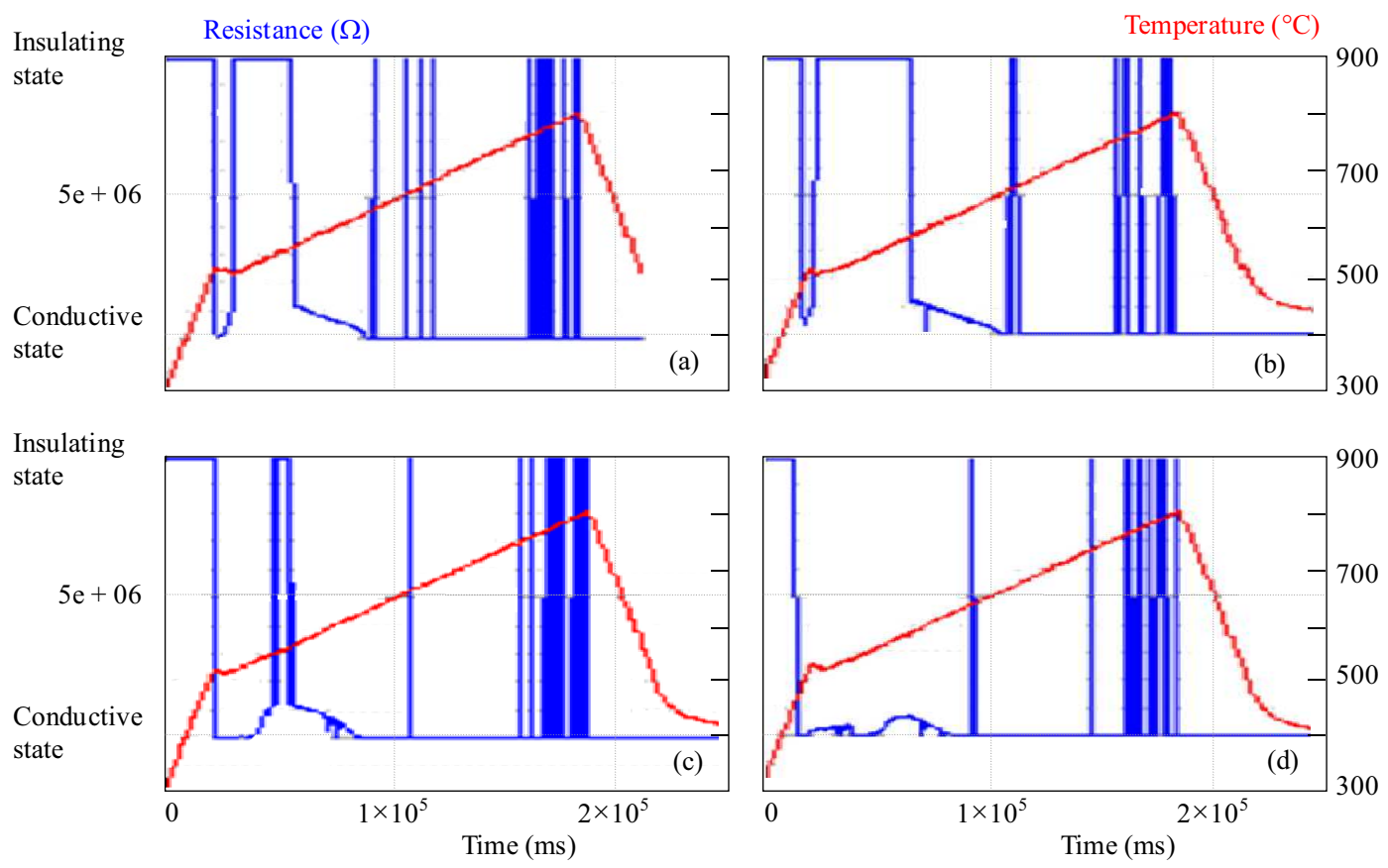

Fig. 1. The dependence of resistance on the temperature and the content of $\mathrm{O}_{2}$ for the paste $\mathrm{A}$

Table 1. Parameters of temperature profiles

\begin{tabular}{c|ccccc}
\hline Time $(\mathrm{s})$ & 0 & 48 & 208 & 278 & 348 \\
Profile 480 Target Temp. ${ }^{\circ} \mathrm{C}$ & 25 & 480 & 800 & 100 & 25 \\
Profile 400 Target Temp. ${ }^{\circ} \mathrm{C}$ & 25 & 400 & 800 & 100 & 25 \\
\hline
\end{tabular}

from the top. K-type thermocouple contacted the sample from the front side to control the temperature during the process. The course of resistance was recorded for temperature above ca. $300{ }^{\circ} \mathrm{C}[4]$.

\section{RESULTS}

The resistance changes for Profile 480 are shown in the Fig. 1 in case of paste A, or in the Fig. 2 in case of paste B. The resistance was alternating between conductive state and insulating state during firing. From resistance dependence on temperature it is obvious that on the beginning there was no conductive connection between testing spots. They were separated from the substrate by deposited antireflection and passivation layer. The burning through the passivation layer at temperature $\nu_{B T}$ is indicated by the first conductive state.

From graphs in Fig. 1 it is evident, that at reduction of $\mathrm{O}_{2}$ concentration the first insulating state became shorter and the temperature $\nu_{B T}$ decreased from $525^{\circ} \mathrm{C}$ (for $21 \% \mathrm{O}_{2}$ ) to $465^{\circ} \mathrm{C}$ (for $0 \% \mathrm{O}_{2}$ ). Between $750{ }^{\circ} \mathrm{C}$ and $800{ }^{\circ} \mathrm{C}$ fluctuations occurred between insulating and conductive state in case of all samples. These fluctuations were most probably caused by rearrangement of silver particles in the liquid glass phase.
In case of paste B (see Fig. 2) the reduction in time of the first insulating state was more significant compared with paste A (Fig. 1). The reduction of $\mathrm{O}_{2}$ concentration decreased the temperature $\nu_{B T}$ from $665^{\circ} \mathrm{C}$ (for $21 \% \mathrm{O}_{2}$ ) to $398 \mathrm{C}$ (for $0 \% \mathrm{O}_{2}$ ). Between $750{ }^{\circ} \mathrm{C}$ and $800{ }^{\circ} \mathrm{C}$ fluctuations occurred between insulating and conductive state in same way as in case of paste A.

From Fig. 1a and the Fig. 3a (paste A), and from Fig. 2a and the Fig. 3b (paste B) it is obvious, that the reduction of the first target temperature $\nu_{H}$ had a bigger impact on the resistance profile of the paste B. Time necessary to burning through the ARC and passivation layer became longer in both cases. The temperature $\nu_{B T}$ decreased from $525^{\circ} \mathrm{C}$ to $480^{\circ} \mathrm{C}$ for paste A, and from $665{ }^{\circ} \mathrm{C}$ to $368^{\circ} \mathrm{C}$ for paste B. Up to $630^{\circ} \mathrm{C}$ the paste $\mathrm{B}$ became conductive and no further insulating state was found. The difference between both pastes is probably that the glasses inside the pastes are activated at different temperatures and as a consequence penetrating the $\mathrm{SiN}_{\mathrm{X}}$ at these different temperatures.

\section{CONCLUSIONS}

The investigation of screen printed thick film metal contacts to boron doped silicon covered with a dielectric passivation layer of $\mathrm{SiO}_{2}-\mathrm{SiN}_{\mathrm{X}}$ is presented. It is obvious that in-situ resistance measurements proved to give insight in the kinetics of contact formation and showed differences in the contact formation process for different $\mathrm{O}_{2}$ concentrations and heating ramps. The temperature required for burning through the passivation and antireflection layer could be determined from the resistance profile. The resistance profile of the paste $\mathrm{B}$ depended more on the $\mathrm{O}_{2}$ content and the first target value $\nu_{H}$ than the 

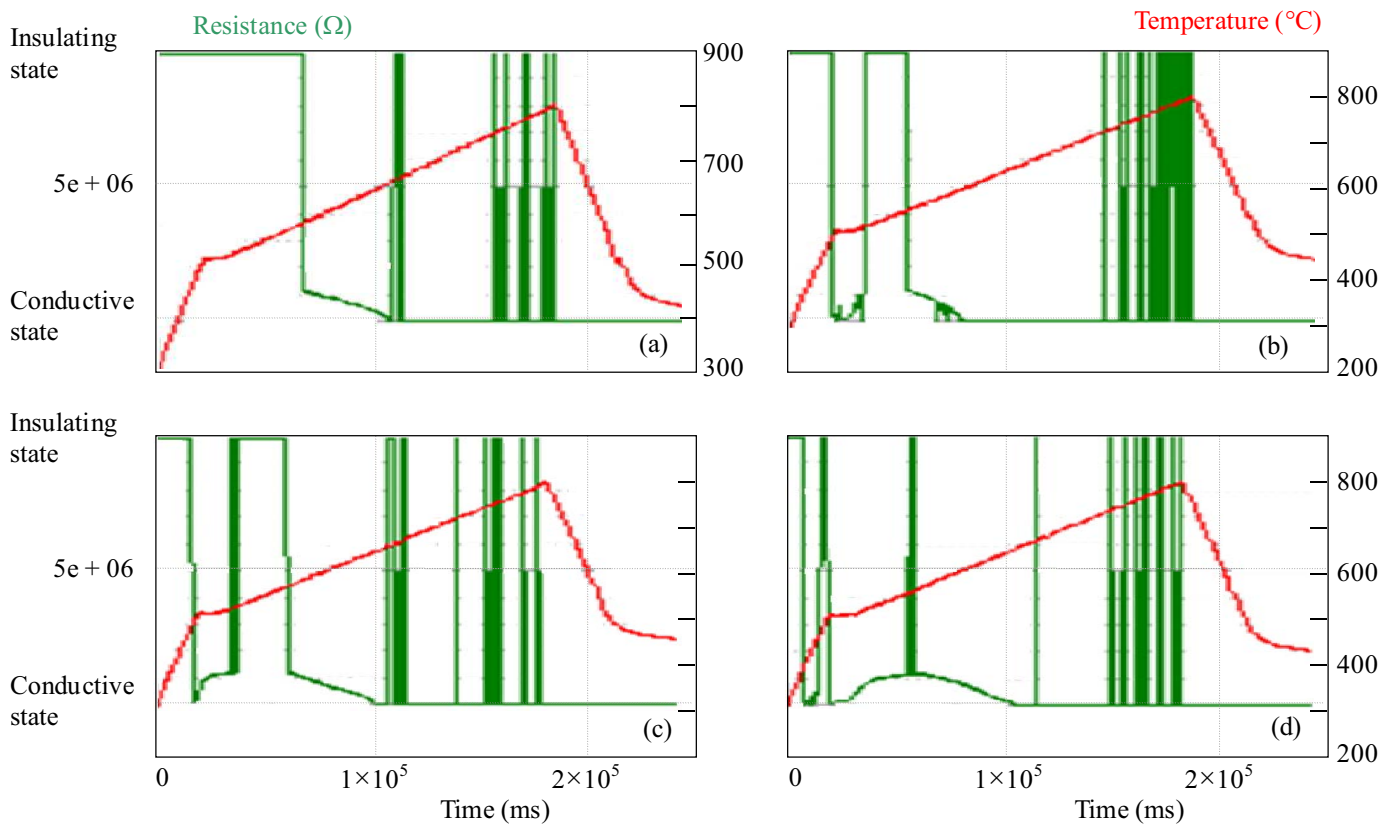

Fig. 2. The dependence of resistance on the temperature and the content of $\mathrm{O}_{2}$ for the paste $\mathrm{B}$
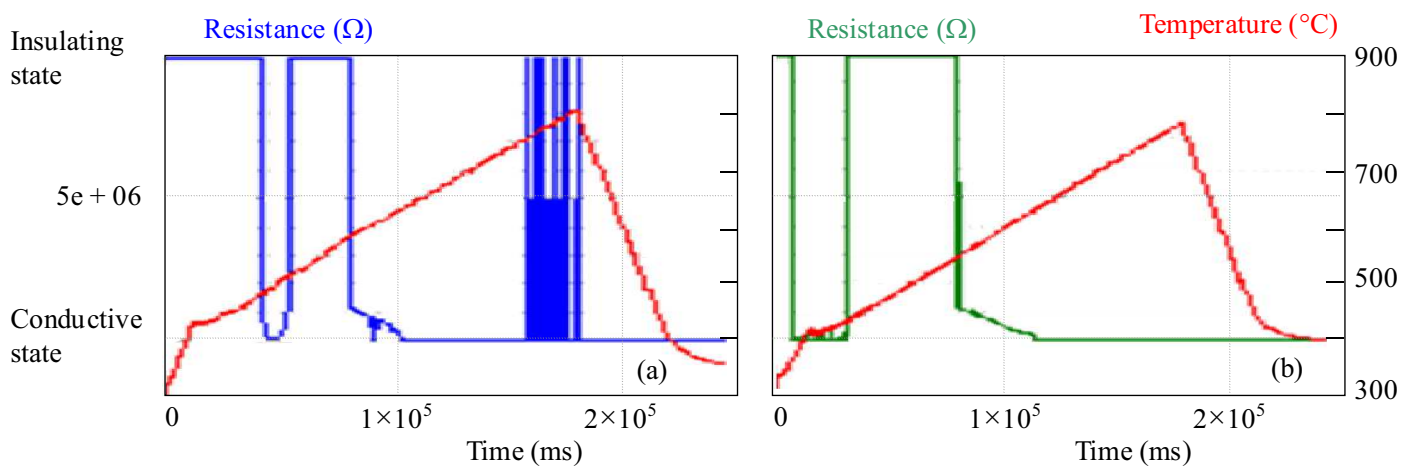

Fig. 3. The dependence of resistance of the paste $\mathrm{A}$ and $\mathrm{B}$ on the temperature for profile $400{ }^{\circ} \mathrm{C}$ with $21 \% \vee_{2}$

profile of the paste A. The temperature $\nu_{B T}$ decreased by reduction of $\mathrm{O}_{2}$ content from $525^{\circ} \mathrm{C}$ to $465^{\circ} \mathrm{C}$ in case of paste $\mathrm{A}$, and from $665^{\circ} \mathrm{C}$ to $398^{\circ} \mathrm{C}$ in case of paste B. The reduction of the first target temperature $\nu_{H}$ extended the time and decreased the temperature $\nu_{B T}$ required for the burning through the ARC and passivation layer.

\section{Acknowledgments}

The article was supported by project FEKT-S-14-2300 A new types of electronic circuits and sensors for specific applications.

\section{REFERENCES}

[1] HÖRTEIS, M. : Fine-Line Printed Contacts on Crystalline Silicon Solar Cells, Konstanz, 2009, Dissertation. Universität Konstanz. Supervised by Gerhard Willeke.

[2] SCHUBERT, G.: Thick Film Metallization of Crystalline Silicon Solar Cells: Mechanism, Models and Applications, Kon- stanz, 2006, Dissertation. Universität Konstanz. Supervised by Prof. Dr. Ernst Bucher.

[3] HONG, K.-K.-CHO, S.-B.-YOU, J. S.-JEONG, J.-W.BEA, S.-M.-HUH, J-Y.: Mechanism for the Formation of Ag Crystallites in the Ag Thick-Film Contacts of Crystalline Si Solar Cells, Solar Energy Materials and Solar Cells 93 No. -7 (2009), 898-904.

[4] BUCK, T.-THEOBALD, J.-NEJATI, M. et al : Engineering and Characterization of Metal Contacts to p+Doped Silicon, In: EU PVSEC Proceedings. Amsterodam: 29th European Photovoltaic Solar Energy Conference and Exhibition, 2014, pp. 401-405.

Received 22 January 2016

Barbora Mojrová (Ing) was born in Jihlava, Czech Republic, in 1989. She finished engineering study at the Department of Electrical and Electronic Technology, Faculty of Electrical Engineering and Communication, Brno University of Technology, in 2013. At present she is a PhD student at Department of Microelectronics and her dissertation research is focused on N-type crystalline silicon solar cells. 